\title{
Analisis Pengaruh Keberhasilan Diri, Toleransi Akan Risiko, dan Kebebasan Dalam Bekerja Terhadap Motivasi Berwirausaha (Studi Kasus Pada Mahasiswa Jurusan Manajemen Universitas Tidar)
}

\author{
Hanifah Sausan Nida ${ }^{1}$, Hanung Eka Atmaja ${ }^{2}$ \\ Program Studi Manajemen, Universitas Tidar Magelang ${ }^{1,2}$
}

Email korespondensi: sausannida09@email.com ${ }^{1}$, hanungekaatmaja@untidar.ac.id $^{2}$

Received: 24 Sept 2021 Reviewed: 14 Oct 2021 Accepted: 26 Oct 2021 Published: 31 Oct 2021

\begin{abstract}
This study aims to identify and analyze the effect of self-efficacy, risk tolerance, and freedom at work on entrepreneurial motivation in students of the Management Department Universitas Tidar. This study uses primary data obtained directly from the object of research through a questionnaire. The primary data was then processed using SPS through the T test, and F test. The results of the $F$ test showed that self-efficacy, risk tolerance, and freedom at work had a significant simultaneous effect on entrepreneurial motivation. The test results based on the ANOVA test or the F statistical test show an F value of 23,964 with a probability of 0.000 meaning that the independent variables can explain together the dependent variable.
\end{abstract}

Keywords: self-success, tolerance of risk, freedom in work, entrepreneurial motivation

\begin{abstract}
ABSTRAK
Penelitian ini bertujuan untuk mengidenfitikasi dan menganalisis pengaruh keberhasilan diri, toleransi akan risiko, dan kebebasan dalam bekerja terhadap motivasi berwirausaha pada mahasiswa Jurusan Manajemen Universitas Tidar. Penelitian ini menggunakan data primer yang diperoleh langsung dari objek penelitian melalui kuisioner. Data primer kemudian diolah menggunakan SPSS yaitu melalui uji asumsi klasik, uji T, dan uji F. Hasil uji F menunjukkan bahwa keberhasilan diri, toleransi akan risiko, dan kebebasan dalam bekerja berpengaruh signifikan secara simultan terhadap motivasi berwirausaha. Hasil pengujian berdasarkan uji ANOVA atau uji statistik F menunjukkan nilai F sebesar 23,964 dengan probabilitas sebesar 0,000 artinya bahwa variabel bebas dapat menjelaskan secara bersama-sama terhadap variabel terikat.
\end{abstract}

Kata kunci: keberhasilan diri, toleransi akan risiko, kebebasan dalam bekerja, motivasi wirausaha

\section{A. PENDAHULUAN}

Saat ini masyarakat Indonesia masih banyak yang kesulitan mencari pekerjaan tetap. Tidak berbeda dengan lulusan mahasiswa, banyak sarjana muda yang masih menjadi pengangguran apalagi ditengah kondisi pandemi seperti sekarang. Keadaan tersebut memicu mayoritas masyarakat untuk berlomba-lomba mencari pekerjaan guna memenuhi kebutuhan sehari-hari. Akibat adanya persaingan yang ketat, peluang adanya lapangan pekerjaan menjadi semakin sempit dan terbatas. Sebagai lulusan perguruan tinggi, sarjana muda seharusnya dapat 
membangun jiwa entrepreneur untuk menciptakan lapangan kerja sendiri di tengah sempitnya lapangan pekerjaan yang ada.

Wirausaha merupakan potensi pembangunan negara, disamping pembangunan pemerintah yang sangat terbatas. Dalam kutipan Drucker (1996), dinyatakan bahwa proses perubahan ekonomi secara keseluruhan bergantung pada entrepreneur. Perekonomian sangat membutuhkan banyak hal yang tidak akan mampu apabila hanya ditunjang oleh pembangunan pemerintah saja. Namun, beberapa hal lain seperti anggaran belanja, personalia maupun pengawasan yang seharusnya diperhatikan. Seperti halnya di negara-negara maju, banyak sekali entrepreneur yang menciptakan produk-produk inovatif sebagai salah satu alternatif untuk memperkaya pasar. Sebagai contoh entrepreneur yang ada di negara Amerika di tahun 1980-an, sebanyak 20 juta orang dapat membuka dan menciptakan lapangan kerja baru. Munculnya entrepreneur baru juga banyak terjadi di negara maju lainnya seperti China dan Eropa bagian Timur.

Jiwa entrepreneur harus ditumbuhkan dengan adanya dorongan dan keinginan untuk memunculkan ide-ide baru dan pola pikir yang kreatif dan inovatif. Suryana (2011) mengatakan bahwa suatu aksioma yaitu tantangan merupakan awal untuk melakukan proses kewirausahaan. Dari tantangan tersebut akan menimbulkan adanya dorongan dan kemauan untuk berinisiatif, serta menjadi lebih inovatif dalam melakukan sesuatu. Oleh karena itu mahasiswa di perguruan tinggi dibekali ilmu berwirausaha pada saat perkuliahan dengan harapan agar mampu menciptakan jiwa entrepreneur itu sendiri dan menerapkannya saat memasuki dunia kerja.

\section{B. TELAAH PUSTAKA}

\section{Motivasi}

Bangun (2012) mengatakan motivasi berasal dari kata motif (motive), yang artinya dorongan. Sastrohadiwiryo (2003) mendefinisikan motivasi sebagai mengarah atau menyalurkan dan juga menggerakkan perilaku untuk mencapai suatu kebutuhan yang nantinya akan memberikan kepuasan. Menurut Hamzah (2007) motivasi adalah usaha dan dorongan dari dalam diri seseorang untuk mengadakan perubahan dalam tingkah lakunya menjadi lebih baik agar dapat memenuhi kebutuhannya.

Gray dalam Winardi (2012) mengartikan motivasi adalah serangkaian proses bagi individu yang sifatnya internal maupun eksternal dan menimbulkan sikap antusias serta persistensi dalam melakukan kegiatan tertentu. Sebagai seorang entrepreneur motivasi dapat 
dijadikan sebuah dorongan dari dalam diri, dan dapat pula dijadikan dorongan yang timbul dari orang lain. Dalam kutipan Winardi (2012) lainnya, Mitchell juga mengartikan motivasi sebagai perwakilan dari proses-proses psikologikal sehingga menyebabkan adanya persistensi kegiatan-kegiatan sukarela yang mengarah ke tujuan tertentu.

Minat berwirausaha mahasiswa dapat dipengaruhi oleh suatu dorongan yaitu adanya rasa percaya diri, timbul sifat kreatif dan inovatif, memiliki jiwa entrepreneur, serta dapat mengatur suatu hal secara efektif dan efisien dan berorientasi pada masa depan (Tama, 2010 dalam Tuskeroh, 2013). Kutipan dari Luthan (2006) mengartikan motivasi sebagai proses permulaan defisiensi fisiologis dan psikologis yang menimbulkan gerakan perilaku atau dorongan dan bertujuan untuk memenuhi suatu capaian atau insentif tertentu. Artinya, hubungan antara dorongan dan insentif menjadi salah satu kata kunci untuk memahami sebuah proses motivasi. Menurut Masrukhin \& Waridin (2006) motivasi merupakan minat individu yang ditunjukkan oleh faktor psikologis terhadap pekerjaan, rasa puas dan dapat bertanggungjawab atas aktivitas atau pekerjaan yang akan dilakukan.

\section{Pengertian Kewirausahaan}

Lupiyoadi (2004) mendefinisikan wirausaha sebagai seseorang yang memiliki kreatifitas dan inovasi dalam mewujudkan suatu usaha demi meningkatkan kesejahteraan dalam dirinya, masyarakat, serta lingkungan di sekitar. Kreatifitas terwujud dengan adanya kemampuan untuk menciptakan sebuah hal baru dan belum pernah ada sebelumnya. Sedangkan inovasi terwujud dengan kemampuan untuk menciptakan sesuatu yang sudah ada kemudian dimodifikasi menjadi sebuah hal yang berbeda dari sebelumnya. Dhewanto (2013) menyatakan bahwa di seluruh dunia intrapreneurship atau kewirausahaan sudah ada dan diterapkan di banyak perusahaan baik itu perusahaan publik maupn swasta yang berkembang dengan pesat seperti negara Amerika Serikat, Afrika, Eropa, hingga Asia. Wirausaha merupakan usaha perpindahan sumber daya ekonomi secara keseluruhan dari daerah yang kurang produktif ke daerah yang lebih produktif sehingga dapat memberikan penghasilan yang semakin besar Widodo (2005).

Schumpeam dalam Alma (2005) mengartikan wirausahawan sebagai usaha mendorong sistem perekonomian yang ada oleh individu dan proses menggerakkan perekonomian masyarakat menjadi lebih maju. Purnomo dalam Tuskeroh (2013) menyebutkan, ciri-ciri seseorang yang memiliki mental wirausaha terdiri dari tujuh kekuatan pribadi antara lain: memiliki kemauan yang keras, memiliki kekuatan secara pribadi, adanya proses memahami diri, percaya diri, dan pengetahuan mengenai tujuan dan kebutuhan, jujur dan tanggung jawab, 
bermoral tinggi dan disiplin, fisik yang kuat, seperti kesehatan jasmani dan rohani, tekun dan ulet untuk bekerja keras, berpikir konstruktif dan kreatif serta berorientasi masa depan.

\section{Motivasi Berwirausaha}

Menurut Kamus Besar Bahasa Indonesia, motivasi merupakan kemauan untuk melakukan sesuatu. Motivasi diartikan sebagai proses bagi individu yang bersifat internal maupun eksternal yang menimbulkan sikap antusias dan persistensi dalam melakukan sesuatu (Gray dalam Winardi, 2012). Motivasi berwirausaha merupakan sesuatu yang mendorong seseorang untuk melakukan kegiatan dan menciptakan energi dengan membuka suatu bisnis atau usaha untuk mencapai kebutuhan, memberikan rasa puas atau meminimalisir ketidakseimbangan (Budiati, 2012).

\section{Keberhasilan Diri}

Basrowi (2011) berpendapat bahwa pencapaian keberhasilan diri merupakan salah satu daya tarik dalam berwirausaha. Menurut Mc Clelland seseorang yang ingin berhasil dan memiliki kebutuhan akan menciptakan suatu hal yang lebih bermanfaat dan efisien dibandingkan sebelumnya dengan berperilaku standart excellent. Gürol \& Atsan (2006) menyatakan entrepreneur didorong dari keinginan dan keberhasilan dalam berwirausaha karena pandangan keberhasilan tersebut diharapkan dapat menjadi hasil yang menguntungkan dan berakhir dalam pencapaian tujuan.

\section{Toleransi Akan Resiko}

Seorang wirausaha biasanya akan menjauhkan diri dari situasi yang berisiko rendah karena adanya tantangan yang kurang dan akan menjauhi risiko yang terlalu tinggi karena berkeinginan untuk mencapai keberhasilan (Basrowi, 2011). Risiko digunakan dan diantisipasi sebagai bahan untuk memperkirakan keinginan wirausaha dimana semakin tinggi toleransi individu dalam menanggapi risiko maka akan semakin tinggi pula insentif seseorang tersebut untuk menjadi wirausaha. Di awal abad ke-18, Richard Cantillon, pertama kali menggunakan entrepreneur dan mengatakan bahwa risiko adalah hal yang harus ditanggung oleh seorang wirausaha. Wirausaha harus berani menghadapi risiko dengan komitmen yang kuat sehingga dapat terus bekerja keras mencapai hasil yang maksimal. Hasil tersebut harus objektif atau nyata, yang merupakan feedback bagi kelancaran kegiatan tersebut (Suryana, 2011).

\section{Kebebasan Dalam Bekerja}

Salah satu karakteristik seorang wirasaha adalah mengutamakan kebebasan dalam bekerja, usaha tersebut dibuktikan dengan situasi dimana mereka sangat mementingkan kepuasan pribadi dalam bekerja, seperti sistem manajemen usaha yang fleksibel dan 
menciptakan struktur organisasi sesuai apa yang mereka inginkan (Saiman, 2009). Kebebasan dalam bekerja adalah kondisi dimana entrepreneur bukan hanya mengutamakan fleksibilitas dalam satu sisi saja namun menghargai kebebasan berwirausaha, misalnya dengan menyelesaikan pekerjaan, memperoleh keuntungan, dan mengatur manajemen waktu secara mandiri (Hendro, 2005).

Beberapa penelitian terdahulu menunjukkan adanya pengaruh keberhasilan diri, toleransi akan risiko dan kebebasan dalam bekerja terhadap motivasi berwirausaha. Salah satunya dalam penelitian Sari (2013), bahwa hasil penelitian menunjukkan adanya pengaruh yang signifikan faktor keberhasilan diri, toleransi akan risiko dan kebebasan dalam bekerja terhadap motivasi berwirausaha Mahasiswa Pendidikan Ekonomi STKIP PGRI Bangkalan dengan sampel penelitian sejumlah 120 orang. Mahesa (2012) dalam penelitiannya yang berjudul "Analisis Faktor-Faktor Motivasi yang Mempengaruhi Minat Berwirausaha pada Mahasiswa S1 Universitas Diponegoro" Semarang juga menunjukkan semua variabel bebas antara lain toleransi akan risiko, kebebasan dalam bekerja, dan keberhasilan diri memiliki pengaruh positif dan signifikan terhadap minat mahasiswa.

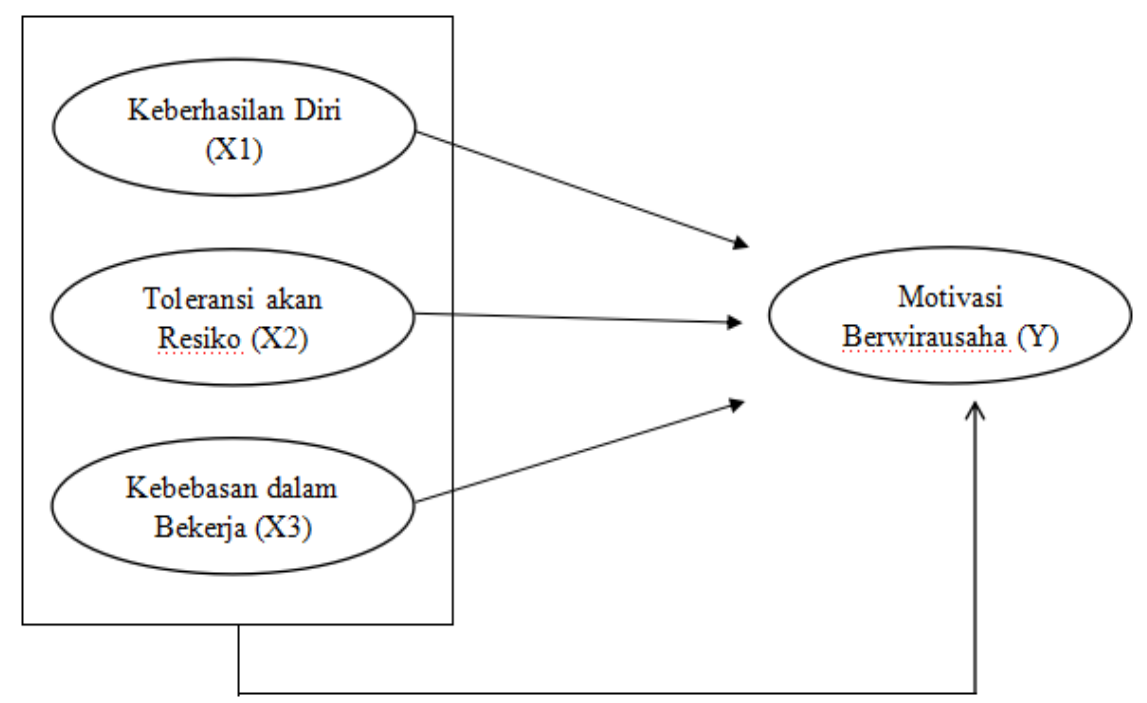

Gambar 1: Kerangka konseptual penelitian

Sumber: Sari (2013)

\section{Hipotesis penelitian}

Dari ulasan kajian pustaka yang telah diungkapkan sebelumnya penulis merumuskan hipotesis sebagai berikut:

$\mathrm{H}_{1}$ : Keberhasilan diri berpengaruh positif terhadap motivasi berwirausaha 
$\mathrm{H}_{2}$ : Toleransi akan resiko berpengaruh positif terhadap motivasi berwirausaha

$\mathrm{H}_{3}$ : Kebebasan dalam bekerja berpengaruh positif terhadap motivasi berwirausaha

$\mathrm{H}_{4}$ : Keberhasilan diri, toleransi akan resiko, dan kebebasan dalam bekerja berpengaruh secara bersama-sama atau simultan terhadap motivasi berwirausaha.

\section{METODE PENELITIAN}

Metode penelitian yang digunakan yaitu metode kuantitatif. Metode kuantitatif digunakan untuk meneliti suatu populasi maupun sampel, dimana teknik pengambilan sampel pada umumnya dilakukan secara acak dan data tersebut dikumpulkan menggunakan instrumen penelitian, kemudian data analisis secara kuantitatif/ statistik dengan tujuan pengujian hipotesis yang telah ditetapkan (Sugiyono, 2014).

\section{Unit dan sampel penelitian}

Penelitian ini dilakukan pada mahasiswa aktif jurusan manajemen di Universitas Tidar Magelang. Populasi dalam penelitian ini yaitu sejumlah 654 mahasiswa aktif Jurusan Manajemen. Menurut Sekaran (2006) jumlah sampel ditentukan berdasarkan ukuran sampel pada umumnya yaitu lebih dari 30 dan kurang dari 500. Teknik penentuan sampel menggunakan purposive sampling dimana penelitian tidak dilakukan oleh seluruh populasi, namun hanya menggunakan sampel dengan kriteria tertentu. Kriteria yang digunakan menargetkan responden yaitu mahasiswa yang memiliki minat untuk berwirausaha dan hanya berlaku untuk mahasiswa semester 3 ke atas. Sampel yang digunakan dalam penelitian ini berjumlah 165 responden.

\section{Metode pengumpulan data}

Data yang diambil dalam penelitian ini yaitu menggunakan data primer. Data primer diperoleh dari data kuisioner oleh responden dengan jawaban berdasarkan skala likert. Sugyiono (2014) menyatakan bahwa pendapat responden terhadap pernyataan memiliki nilai 5 untuk setiap alternatif jawaban sangat setuju (SS); nilai 4 untuk setiap alternatif jawaban setuju (S); nilai 3 untuk setiap alternatif jawaban netral/ragu-ragu $(\mathrm{N})$; nilai 2 untuk setiap alternatif jawaban tidak setuju (TS); nilai 1 untuk setiap alternatif jawaban sangat tidak setuju (STS).

\section{Teknik analisis data}

Analisis data dalam penelitian ini menggunakan analisis kuantitatif. Data yang diperoleh diuji secara langsung menggunakan software SPSS. Metode yang digunakan untuk 
menganalisis penelitian yaitu: analisis regresi linear berganda melalui beberapa uji, antara lain Uji Asumsi Klasik, Uji T, dan Uji F.

\section{HASIL DAN PEMBAHASAN}

\section{Uji Asumsi Klasik}

1. Uji Normalitas

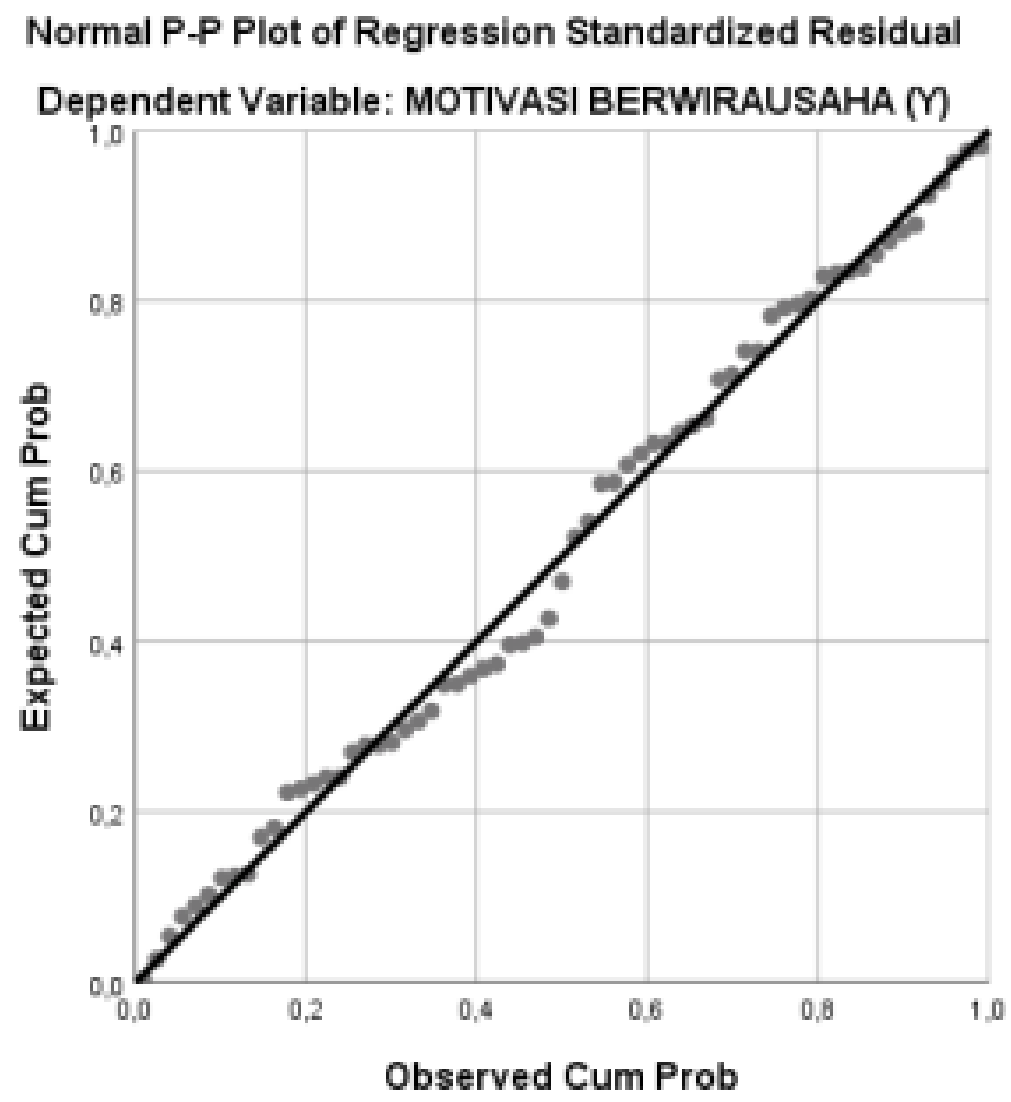

Gambar 2: Uji Normalitas

Menurut Ghozali (2016), model regresi dikatakan berdistribusi normal apabila data titiktitik (ploting) yang menggambarkan data sesungguhnya mengikuti garis diagonal. Pada hasil output penelitian menggunakan SPSS terlihat bahwa plot pada gambar mengikuti garis diagonal, artinya model regresi tersebut berdistribusi normal.

2. Uji Multikolinearitas

Uji multikolinearitas digunakan untuk mengetahui hubungan antar sesama variabel independen. Menurut Ghozali (2011), model tidak mengalami gejala multikolinearitas apabila nilai tolerance $>0,100$ dan nilai VIF $<10,00$. Ditunjukkan pada tabel coefficients pada bagian kolom tolerance dan VIF, nilai tolerance ketiga variabel > 0,100 dan nilai VIF ketiga variabel 
$<10,00$. Dari hasil tersebut menunjukkan tidak adanya gejala multikolinearitas antara variabel bebas dalam model regresi.

Tabel 1: Hasil Uji Multikolinearitas

Coefficients $^{\mathbf{a}}$

\begin{tabular}{|c|c|c|c|c|c|c|c|c|}
\hline & \multirow[t]{2}{*}{ Model } & \multicolumn{2}{|c|}{$\begin{array}{c}\text { Unstandardized } \\
\text { Coefficients }\end{array}$} & \multirow{2}{*}{$\begin{array}{c}\text { Standardized } \\
\text { Coefficients } \\
\text { Beta }\end{array}$} & \multirow[t]{2}{*}{$\mathrm{t}$} & \multirow[t]{2}{*}{ Sig. } & \multicolumn{2}{|c|}{$\begin{array}{l}\text { Collinearity } \\
\text { Statistics }\end{array}$} \\
\hline & & $\mathrm{B}$ & Std. Error & & & & Tolerance & VIF \\
\hline \multirow[t]{4}{*}{1} & (Constant) &,- 743 & 2,770 & &,- 268 & ,789 & & \\
\hline & Keberhasilan diri $\left(\mathrm{X}_{1}\right)$ & ,536 & ,130 & 477 & 4,130 & ,000 & ,565 & 1,769 \\
\hline & $\begin{array}{l}\text { Toleransi akan resiko } \\
\left(\mathrm{X}_{2}\right)\end{array}$ & ,316 & ,133 & 289 & 2,383 & ,020 & ,513 & 1,949 \\
\hline & $\begin{array}{l}\text { Kebebasan dalam } \\
\text { bekerja }\left(\mathrm{X}_{3}\right)\end{array}$ & 153 & 132 & 107 & 1,152 & ,254 & 876 & 1,141 \\
\hline
\end{tabular}

a. Dependent Variable: Motivasi berwirausaha (Y)

Sumber: Data primer yang diolah, 2021

3. Uji Heteroskedastisitas

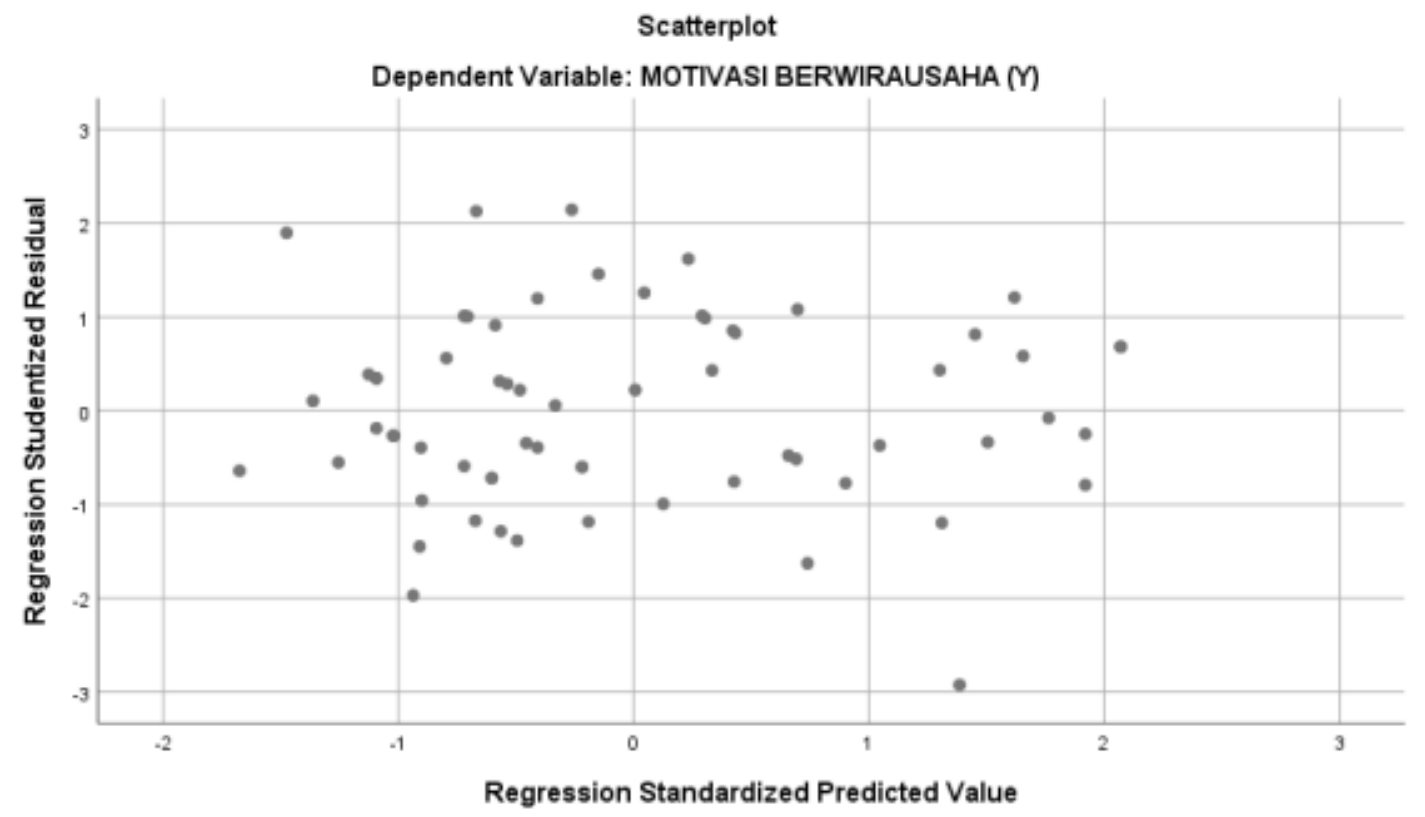

Gambar 3: Scatterplots

Menurut Ghozali (2011) apabila pada gambar scatterplots tidak ada pola yang jelas (bergelombang, melebar, dan menyempit), serta titik-titik menyebar di atas dan dibawah angka 0 pada sumbu Y maka tidak terjadi heteroskedastisitas. Hasil penelitian menunjukkan bahwa penyebaran residual pada gambar tidak teratur, artinya tidak ada gejala heteroskedastisitas pada model. 


\section{Analisis Regresi Linear Berganda}

Berdasarkan pada analisis data menggunakan SPSS Statistics 25 dan dilihat pada tabel coefficients, diperoleh hasil persamaan sebagai berikut:

$\mathrm{Y}=-0,743+0,536 X_{1}+0,316 X_{2}+0,153 X_{3}+\mathrm{e}$

Dari persamaan tersebut menunjukkan ketiga variabel bebas memiliki koefisien regresi yang bernilai positif. Artinya, apabila keberhasilan diri, toleransi akan resiko, dan kebebasan dalam bekerja semakin tinggi atau mengalami peningkatan maka motivasi dalam berwirausaha mahasiswa akan meningkat pula.

Tabel 2: Koefisien Determinasi

\begin{tabular}{rrrrrr}
\hline \multicolumn{5}{c}{ Model Summary $^{\mathbf{b}}$} \\
\hline Model & $\mathrm{R}$ & $\mathrm{R}$ Square & $\begin{array}{c}\text { Adjusted R } \\
\text { Square }\end{array}$ & $\begin{array}{l}\text { Std. Error of } \\
\text { the Estimate }\end{array}$ & $\begin{array}{c}\text { Durbin- } \\
\text { Watson }\end{array}$ \\
\hline 1 &, $735^{\mathrm{a}}$ &, 541 &, 518 & 1,913 & 1,828 \\
\hline
\end{tabular}

a. Predictors: (Constant), kebebasan dalam bekerja $\left(\mathrm{X}_{3}\right)$, keberhasilan diri $\left(\mathrm{X}_{1}\right)$, toleransi akan resiko $\left(\mathrm{X}_{2}\right)$

b. Dependent Variable: motivasi berwirausaha (Y)

Dilihat dari tabel 2 hasil perhitungan regresi menunjukkan bahwa koefisien determinasi (Adjusted $\mathrm{R}^{2}$ ) yang dihasilkan sebesar 0,518 artinya 51,8\% variabel terikat yaitu motivasi berwirausaha dapat dijelaskan oleh variabel bebasnya yaitu keberhasilan diri, toleransi akan resiko dan kebebasan dalam bekerja. Sedangkan 48,2\% sisanya dijelaskan oleh variabel lainnya.

Tabel 3: Uji Statistik F

\begin{tabular}{|c|c|c|c|c|c|}
\hline \multicolumn{6}{|c|}{$\overline{\text { ANOVA }^{\mathrm{a}}}$} \\
\hline Model & $\begin{array}{l}\text { Sum of } \\
\text { Squares }\end{array}$ & df & $\begin{array}{c}\text { Mean } \\
\text { Square }\end{array}$ & $\mathrm{F}$ & Sig. \\
\hline 1 Regression & 262,791 & 3 & 87,597 & 23,946 &, $000^{\mathrm{b}}$ \\
\hline Residual & 223,147 & 61 & 3,658 & & \\
\hline Total & 485,938 & 64 & & & \\
\hline
\end{tabular}

a. Dependent Variable: motivasi berwirausaha (Y)

b. Predictors: (Constant), kebebasan dalam bekerja (X3), keberhasilan diri (X1), toleransi akan resiko (X2)

Dilihat dari tabel 3 hasil pengujian berdasarkan uji ANOVA atau uji statistik $\mathrm{F}$ menunjukkan nilai $F$ sebesar 23,964 dengan probabilitas sebesar 0,000. Nilai $F_{\text {tabel }}=(\mathrm{k} ; \mathrm{n}-\mathrm{k})$ $=(3 ; 65-3), F_{\text {tabel }}=(3 ; 62)=2,76$ yang artinya $F_{\text {hitung }}$ lebih besar dari $F_{\text {tabel }}(23,946>2,76)$. 
Dalam hal ini maka semua variabel bebas dapat menjelaskan secara bersama-sama atau simultan yang signifikan terhadap variabel terikat.

Jika dilihat pada tabel 1 hasil uji t secara parsial penelitian ini menunjukkan beberapa hasil. Variabel keberhasilan diri $\left(X_{1}\right)$ berpengaruh positif dan signifikan terhadap motivasi berwirausaha mahasiswa jurusan manajemen Universitas Tidar. Hal ini ditunjukkan oleh signifikansi variabel keberhasilan diri $\left(X_{1}\right)$ adalah $0,000<0,05$. Nilai $t_{\text {tabel }}=(\alpha / 2 ; \mathrm{n}-\mathrm{k}-1)=$ $(0,05 / 2 ; 65-3-1)=(0,025 ; 61)=2,000$ dimana $t_{\text {hitung }}$ lebih besar dari $t_{\text {tabel }}(4,130>2,000)$ maka $H_{0}$ ditolak dan $H_{1}$ diterima. Variabel toleransi akan resiko $\left(X_{2}\right)$ berpengaruh positif dan signifikan terhadap motivasi berwirausaha mahasiswa jurusan manajemen Universitas Tidar. Hal ini ditunjukkan oleh signifikansi variabel toleransi akan resiko $\left(X_{2}\right)$ adalah $0,020<0,05$. Nilai $t_{\text {tabel }}=(\alpha / 2 ; \mathrm{n}-\mathrm{k}-1)=(0,05 / 2 ; 65-3-1)=(0,025 ; 61)=2,000$ dimana $t_{\text {hitung }}$ lebih besar dari $t_{\text {tabel }}(2,383>2,000)$ maka $H_{0}$ ditolak dan $H_{2}$ diterima. Variabel kebebasan dalam bekerja $\left(X_{3}\right)$ tidak berpengaruh secara signifikan terhadap motivasi berwirausaha mahasiswa jurusan manajemen Universitas Tidar. Hal ini ditunjukkan oleh signifikansi variabel toleransi akan resiko $\left(X_{2}\right)$ adalah $0,020<0,05$. Nilai $t_{\text {tabel }}=(\alpha / 2 ; \mathrm{n}-\mathrm{k}-1)=(0,05 / 2 ; 65-3-1)=(0,025 ; 61)=$ 2,000 dimana $t_{\text {hitung }}$ lebih kecil dari $t_{\text {tabel }}(1,152>2,000)$ maka $H_{3}$ ditolak.

\section{Pembahasan}

1. Pengaruh keberhasilan diri terhadap motivasi berwirausaha

Keberhasilan diri dalam temuan ini berpengaruh signifikan dan positif terhadap motivasi berwirausaha mahasiswa. Keberhasilan diri dapat menjadi salah satu faktor untuk meningkatkan jiwa kewirausahaan pada mahasiswa. Seperti dalam penelitian sebelumnya yang dilakukan oleh Tama (2010), bahwa kepercayaan akan keberhasilan diri dapat menjadikan motivasi untuk berwirausaha lebih besar. Jika seseorang ingin menggapai tujuan, maka harus mencapai keberhasilan.

\section{Pengaruh toleransi akan risiko terhadap motivasi berwirausaha}

Temuan ini menunjukkan bahwa keberhasilan risiko berpengaruh positif dan signifikan terhadap motivasi berwirausaha mahasiswa. Toleransi akan risiko yang besar dapat meningkatkan semangat dan kemandirian untuk menghadapi tantangan berwirausaha. Hasil penelitian ini didukung oleh penelitian sebelumnya yaitu penelitian Widhari \& Suarta (2012), dan penelitian lainnya. Mahasiswa membuktikan adanya antusias dan keberanian dalam menghadapi risiko serta membentuk mental berwirausaha yang kuat sehingga nantinya dorongan dan motivasi untuk berwirausaha menjadi lebih besar. 
3. Pengaruh kebebasan dalam bekerja terhadap motivasi berwirausaha

Temuan pada variabel ketiga ini tidak menunjukkan adanya pengaruh yang signifikan terhadap motivasi berwirausaha. Namun, hasil penelitian ini mendukung penelitian sebelumnya yang dilakukan oleh Sari (2013) bahwa toleransi risiko tidak berpengaruh terhadap motivasi berwirausaha. Penelitian ini bertentangan dengan hasil temuan Widhari \& Suarta (2012) dimana keduanya membuktikan adanya pengaruh yang signifikan kebebasan dalam bekerja terhadap motivasi berwirausaha. Mahasiswa di Universitas Tidar tidak cukup mementingkan kebebasan dalam bekerja sebagai bentuk dorongan untuk berwirausaha.

4. Pengaruh keberhasilan diri, toleransi akan risiko, dan kebebasan dalam bekerja berpengaruh secara bersama-sama terhadap motivasi berwirausaha

Hasil pengujian menunjukkan bahwa keberhasilan diri, toleransi akan risiko dan kebebasan dalam bekerja berpengaruh positif dan signifikan secara bersama-sama terhadap motivasi berwirausaha mahasiswa. Artinya, semakin tinggi keberhasilan diri, toleransi akan risiko dan kebebasan dalam bekerja pada mahasiswa akan meningkatkan motivasi berwirausaha. Sebaliknya, apabila ketiga faktor tersebut semakin rendah maka motivasi berwirausaha pada mahasiswa akan menurun. Hal ini sesuai dengan penelitian sebelumnya seperti pada penelitian yang dilakukan oleh Sari (2013). Temuan ini dapat menjadi faktor pendorong mahasiswa di Universitas Tidar untuk meningkatkan semangat dan motivasi berwirausaha seperti diantaranya optimis, tekun dan ulet, serta fokus pada tujuan dan berorientasi masa depan.

\section{E. KESIMPULAN}

Berdasarkan hasil analisis data dan pembahasan yang telah diuraikan di atas, maka dapat ditarik simpulan yaitu keberhasilan diri, toleransi akan resiko, dan kebebasan dalam bekerja memiliki pengaruh positif dan signifikan secara bersama-sama terhadap motivasi berwirausaha pada mahasiswa jurusan manajemen Universitas Tidar. Secara parsial, keberhasilan diri dan toleransi akan resiko berpengaruh positif dan signifikan terhadap motivasi berwirausaha pada mahasiswa. Namun, sebaliknya kebebasan dalam bekerja tidak berpengaruh signifikan terhadap motivasi berwirausaha pada mahasiswa. Dari ketiga faktor tersebut, keberhasilan diri merupakan faktor yang berpengaruh paling besar terhadap motivasi berwirausaha pada mahasiswa jurusan manajemen Universitas Tidar.

Saran yang dapat diberikan penulis dalam penelitian ini yaitu perlu adanya upaya dari universitas untuk meningkatkan kompetensi dan skill mahasiswa jurusan manajemen 
Universitas Tidar sebagai bentuk dukungan penuh untuk mengembangkan jiwa kewirausahaan.

Selain itu, mahasiswa sebaiknya juga ikut berperan aktif dalam mengembangkan kreatifitas dalam diri dengan mengikuti kegiatan yang berkaitan dengan dunia kewirausahaan, seperti PKM Kewirausahaan dan yang lainnya. Adanya penelitian ini diharapkan dapat dijadikan referensi untuk penelitian selanjutnya.

\section{DAFTAR PUSTAKA}

Alma, B. (2011). Kewirausahaan untuk Mahasiswa dan Umum. Bandung: Alfabeta.

Bangun, W. (2012). Manajemen Sumber Daya Manusia. Jakarta: Erlangga.

Basrowi. (2011). Kewirausahaan Untuk Perguruan Tinggi. Jakarta: Ghalia Indonesia.

Budiati, Y., Yani, T.E., \& Universari, N. (2012). Minat Mahasiswa Menjadi Wirausaha (Studi Pada Mahasiswa Fakultas Ekonomi Universitas Semarang). Jurnal Dinamika Sosbud. 14(1), 89-100.

Dhewanto, W. (2013). Intrapreneurship. Bandung: Rekayasa Sains.

Drucker, P. (1996). Inovasi dan Kewirausahaan. Jakarta: Erlangga.

Ghozali, I. (2011). Aplikasi Analisis Multivariate dengan Program SPSS (5 ed.). Semarang: Badan Penerbit Universitas Diponegoro.

Gürol, Y., \& Atsan, N. (2006). Entrepreneaurial characteristics amongst university students: Some insights for entrepreneurship education and training in Turkey. Education and Training, 48, 25-38

Hamzah, U. B. (2007). Teori Motivasi \& Pengukurannya Analisis di Bidang Pendidikan. Jakarta: Bumi Aksara.

Hendro. (2005). How to become a smart entrepreneur and to start a new business. Yogyakarta: Penerbit Andi.

Lupiyoadi, R. (2004). Manajemen Pemasaran Jasa: Teori Dan Pratek. Jakarta: Salemba Empat.

Luthan, F. (2006). Perilaku Organisasi (10 ed.). Yogyakarta: Penerbit Andi.

Mahesa, A.D. (2012). Analisis Faktor-Faktor Motivasi yang Mempengaruhi Minat Berwirausaha (studi pada Mahasiswa S1 Fakultas Ekonomika dan Bisnis Universitas Diponegoro).Skripsi UNDIP

Masrukhin \& Waridin. (2006). Pengaruh Motivasi Kerja, Kepuasan Kerja, Budaya Organisasi dan Kepemimpinan terhadap Kinerja Pegawai. Jurnal Ekonomi \& Bisnis, 7(2).

Saiman, L. (2009). Kewirausahaan Teori, Praktik, dan Kasus-Kasus. Jakarta: Salemba Empat.

Sari, I. P. 2013. Pengaruh Keberhasilan Diri, Toleransi Akan Risiko, Dan Kebebasan Dalam Bekerja Terhadap Motivasi Berwirausaha Pada Mahasiswa Program Studi Pendidikan Ekonomi STKIP PGRI Bangkalan. Jurnal Ekonomi Pendidikan dan Kewirausahaan, 1(1). 
Sastrohadiwiryo S. (2003). Manajemen Tenaga Kerja Indonesia, Pendekatan Administrasi dan Operasional. Jakarta: Bumi Aksara.

Sekaran, U. (2006). Metode Penelitiaan Bisnis. Salemba Empat: Jakarta.

Sugiyono. (2014). Metode Penelitian Pendidikan Pendekatan Kuantitatif, Kualitatif, dan R\&D. Bandung: Alfabeta.

Suryana. (2011). Kewirausahaan pedoman Praktis: Kiat dan Proses Menuju Sukses. Jakarta: Salemba Empat.

Tama, A. A. (2010). Analisis faktor-faktor yang memotivasi mahasiswa berkeinginan menjadi entrepreneur. Skripsi UNDIP

Tuskeroh. (2013). Pengaruh Motivasi dan Mental Berwirausaha pada Mahasiswa Akuntasnsi Universitas Maritim Raja Ali Haji. Jurnal Akuntansi. 1-17.

Widhari, C.I.S \& Suarta, I.K. (2012). Analisis Faktor-faktor yang Memotivasi Mahasiswa Berkeinginan Menjadi Wirausaha. Jurnal Bisnis dan Kewirausahaan, 8(1).

Widodo, W.D. (2005). Jendela Cakrawala Kewirausahaan. Bogor: IPB Press.

Winardi. (2012). Manajemen Sumber Daya Manusia, Edisi Ketiga. Jakarta: Rineka Cipta. 